\title{
Pengaruh Kemampuan Penalaran, Efikasi Diri dan Kemampuan Memecahkan Masalah Terhadap Penguasaan Konsep Matematika
}

\author{
Stefy Falentino Akuba ${ }^{1 *}$, Dian Purnamasari ${ }^{2}$, Robby Firdaus ${ }^{3}$ \\ 1,2,3Sekolah Pascasarjana Manajemen, Universitas Pelita Harapan, Banten, Indonesia; \\ ${ }^{1 *}$ stefyakuba@gmail.com
}

Info Artikel: Dikirim: 22 November 2019; Direvisi: 8 Februari 2020; Diterima: 4 Maret 2020

Cara sitasi: Akuba, S. F., Purnamasari, D., \& Firdaus, R. (2020). Pengaruh Kemampuan Penalaran, Efikasi Diri dan Kemampuan Memecahkan Masalah Terhadap Penguasaan Konsep Matematika. JNPM (Jurnal Nasional Pendidikan Matematika), 4(1), 44-60.

\begin{abstract}
Abstrak. Pada suatu sekolah dasar, sebut saja X, pencapaian akademis siswa dalam pelajaran matematika diukur oleh tingkat penguasaan konsep. Kemampuan penalaran matematis, kemampuan memecahkan masalah dan efikasi diri siswa dapat memiliki pengaruh terhadap tingkat penguasaan konsep. Penelitian ini dilakukan dengan tujuan untuk mengetahui pengaruh dari kemampuan penalaran matematis, efikasi diri dan kemampuan memecahkan masalah terhadap penguasaan konsep pelajaran matematika. Metode penelitian ini adalah metode kuantitatif dengan jenis penelitian kausal-komparatif. Pengolahan data dengan teknik analisis jalur menggunakan software smart PLS 3.0. Hasil analisis data menunjukkan bahwa kemampuan penalaran matematis, efikasi diri dan kemampuan memecahkan masalah berpengaruh positif terhadap penguasan konsep dengan koefisien jalur secara berurutan adalah $0.453,0.175$ dan 0.395 . Selanjutnya, kemampuan penalaran matematis juga berpengaruh positif terhadap efikasi diri dan kemampuan memecahkan masalah dengan koefisien jalur secara berurutan adalah 0.425 dan 0.560 . Melalui hasil penelitian ini, ketika siswa mengalami penurunan saat ujian, sekolah dasar $X$ dapat memberikan pelajaran yang mampu meningkatkan kemampuan penalaran, efikasi diri dan kemampuan memecahkan masalah.
\end{abstract}

Kata Kunci: Kemampuan Penalaran, Efikasi Diri, Kemampuan Memecahkan Masalah, Penguasaan Konsep.

Abstract. In an elementary school, named $X$, the academic achievement of students in mathematics was measured based on the concept mastery. Mathematical reasoning ability, problem-solving ability, and students' self-efficacy could affect students' concept mastery. This study aimed to identify the effect of mathematical reasoning ability, self-efficacy, and problem-solving ability towards mathematics concept mastery. This research used a path coefficient as a result of data analysis using SEM method with smartPLS 3.0 software as the tool. The result showed that mathematical reasoning ability, self-efficacy, and problemsolving ability showed a positive effect on concept mastery with the values of path coefficient, 
respectively .453, .017, and .395. Mathematical reasoning ability also affected the selfefficacy and problem-solving ability positively with the values of path coefficient, respectively .425 and .560. Therefore, when students got a decrease in examinations, $X$ elementary school could provide lessons that could improve the ability of reasoning, selfefficacy, and the ability to solve problems.

Keywords: Mathematical Reasoning, Self-Efficacy, Problem-Solving Ability, Concept Mastery.

\section{Pendahuluan}

Menurut peraturan pemerintah Indonesia, sekolah yang menggabungkan kurikulum nasional dan kurikulum lain dimasukan dalam kategori Satuan Pendidikan Kerjasama (SPK). Sekolah dasar X adalah salah satu SPK di Jakarta yang memakai kurikulum Cambridge dalam pelajaran inti seperti matematika, namun tetap diwajibkan untuk mengikutkan siswanya dalam ujian nasional yang bahannya disusun dengan kurikulum nasional. Hal tersebut menyebabkan kebingungan guru matematika untuk menyusun pembelajaran. Dari hasil kuisioner yang diisi oleh para guru, mereka menyadari banyak kompetensi yang penting namun guru lebih banyak menitikberatkan kemampuan siswa dalam penguasaan konsep saja demi menyiapkan siswa untuk lulus tes terstandarisasi seperti ujian nasional.

Mendidik siswa agar memiliki penguasaan konsep adalah solusi yang efektif dalam meningkatkan kemampuan matematika siswa hingga ke level yang diekspektasikan (Garry, 2020). Guru-guru matematika di sekolah X menyadari hal tersebut namun dalam eksekusinya siswa hanya menjalani latihan soal tanpa mengalami variasi yang berbeda dalam aktivitas kelas. Dengan kegiatan yang monoton serta siswa diharapkan mendapatkan hasil yang baik dalam ujian, menyebabkan kemampuan penalaran matematis, efikasi diri pada siswa dan kemampuan memecahkan masalah tidak diperhatikan. Ironisnya menurut hasil kuisioner, guru menilai tiga hal tersebut sangat penting untuk dimiliki siswa dalam pelajaran matematika.

Sekolah dasar $\mathrm{X}$ menjadikan penguasaan konsep sebagai faktor yang menentukan ketuntasan siswa dalam pelajaran dan hal tersebut kemudian diukur melalui tes sumatif. Pada dasarnya, penguasaan konsep adalah indikator penting untuk menilai hasil belajar yang didapat oleh siswa. Faktor-faktor yang mempengaruhi penguasaan konsep siswa adalah tingkat intelegensi siswa, kemampuan siswa dalam memperhatikan, minat siswa, bakat dalam diri siswa, tingkat motivasi siswa, tingkat kematangan, tingkat kelelahan, strategi pembelajaran, pendekatan pembelajaran, keterampilan berpikir dan tingkat kompetensi (kognitif, afektif dan psikomotorik) siswa (Santrock, 2011). 
Penguasaan konsep matematika adalah kemampuan menuangkan ide abstrak yang ditemukan dalam matematika ke dalam contoh yang dapat dipahami dengan jelas serta mengaplikasikan konsep dengan menyajikannya dalam bentuk kalimat matematika untuk memecahkan masalah (Gusniwati, 2015). Penguasaan konsep adalah bobot yang menghubungkan informasi yang berada dalam konsep yang dipahami dengan pola yang sudah dimiliki dengan asas kebermaknaan (Wong, 2004). Dapat disimpulkan, penguasaan konsep matematika adalah kemampuan siswa dalam mengerti ide yang abstrak dengan menghubungkan pola yang sudah dimiliki di dalam pikiran serta menyajikannya dalam kalimat matematika yang dapat dipahami.

Revisi Taksonomi Bloom terdiri dari enam tingkatan kognitif yaitu, mengingat, memahami, mengaplikasikan, menganalisis, mengevaluasi dan menciptakan (McInerney, 2014). Penelitian ini akan memakai hal tersebut sebagai indikator bahwa siswa memiliki penguasaan konsep yang baik yang dijabarkan menjadi enam tingkatan yaitu mengingat, memahami, mengaplikasikan, menganalisis, mengevaluasi dan menciptakan. Mengingat adalah siswa mampu memanggil kembali informasi yang tersimpan di dalam ingatan mereka, memahami adalah kemampuan siswa untuk membangun pengertian berdasarkan pengetahuan awal yang sudah lebih dulu dimiliki, mengaplikasikan adalah siswa dapat memakai suatu prosedur untuk mengerjakan tugas atau menyelesaikan masalah, menganalisis adalah kemampuan siswa untuk mengurai sebuah permasalahan menjadi unsurunsur dasarnya dan menarik keterkaitan antara unsur-unsur tersebut, mengevaluasi adalah siswa mampu membangun suatu pertimbangan yang didasarkan kriteria, batasan dan standar yang ada, dan menciptakan adalah kemampuan siswa dalam membuat pengetahuan baru dari menggabungkan beberapa unsur menjadi satu kesatuan. Keenam tahapan tersebut dipakai menjadi indikator dalam menyusun tes sumatif untuk mengukur penguasaan konsep siswa.

Salah satu kompetensi inti pelajaran matematika dalam kurikulum Cambridge (IGCSE, 2014) dan juga kurikulum nasional adalah kemampuan penalaran matematis (Kemendikbud, 2014). Ironisnya beberapa penelitian menemukan bahwa kemampuan penalaran matematika siswa di Indonesia masih berada di level yang rendah (Ratnasari \& Abadi, 2018; Sukirwan, Darhim, \& Herman, 2018). Kemampuan penalaran matematis adalah kemampuan yang membuat seseorang dapat menghubungkan antara premis-premis yang berguna untuk menghasilkan dugaan dengan proses 
membuat kesimpulan matematis yang logis (Nickerson, 2011). Penalaran matematis adalah penalaran yang digunakan dalam konteks matematika (Brodie, Coetzee, Lauf, Modau, Molefe, \& O’Brien, 2010), di mana matematika memiliki empat cabang utama yaitu teori angka, aljabar, geometri dan analisis. National Governors Association Center for Best Practices $\mathcal{E}$ Council of Chief State School Officers mendefenisikan penalaran matematis sebagai sebuah kemampuan membangun pengertian konsep matematika dalam cara yang logis untuk membentuk sebuah kesimpulan atau penilaian (Higgins, Crawford, Angelo, \& Horney, 2015)

Penalaran matematis didasari pada kemampuan seseorang mencari solusi, melaksanakan penilaian dan menerapkan pemikiran matematis (Mevarech \& Kramarski, 2014). Dapat disintesiskan bahwa kemampuan penalaran matematis adalah kemampuan seseorang dengan menggunakan pikirannya menarik sebuah kesimpulan berdasarkan premis-premis matematis yang ada dan diyakini benar, dengan cara melihat hubungan-hubungan yang ada di antara premis-premis tersebut. Terdapat enam indikator kemampuan penalaran matematis siswa pada Permendikbud nomor 58 tahun 2014, yaitu: siswa mampu mengajukan dugaan, mampu melakukan manipulasi matematika, mampu menarik kesimpulan, menyusun bukti, memberikan alasan atau bukti terhadap kebenaran solusi, mampu menarik kesimpulan dari pernyataan, mampu memeriksa kesahihan suatu argument dan mampu menemukan pola atau sifat dari gejala matematis untuk membuat generalisasi. Keenam indikator tersebut menjadi acuan instrument penelitian untuk mengukur kemampuan penalaran matematis siswa

Sejak diperkenalkan oleh Bandura, efikasi diri dieksplor oleh para peneliti di berbagai bidang termasuk pendidikan (Wentzel \& Miele, 2016), beberapa penelitian menemukan hubungan yang kuat antara efikasi diri terhadap proses belajar seorang siswa (Dogan, 2015; Fitzpatrick, 2018; Olivier, Archambault, De Clercq, \& Galand, 2019). Efikasi diri merujuk pada keyakinan akan kemampuan seseorang untuk mendorong motivasi, kemampuan kognitif dan tindakan yang dibutuhkan untuk memenuhi tuntutan pada situasi tertentu. Efikasi diri adalah sebuah kepercayaan terhadap kemampuan diri sendiri untuk menyelesaikan masalah yang didasari oleh kegagalan dan keberhasilan pribadi di waktu yang lalu (Ormrod, 2012). Berdasarkan penjabaran di atas dapat disintesiskan bahwa efikasi diri adalah keyakinan seseorang pada kemampuan atau kompetensi dirinya sendiri untuk menyelesaikan suatu tugas dan mencapai suatu hasil dalam kondisi tertentu. 
Indikator yang dapat dipakai untuk mengetahui tingkat efikasi diri siswa, yaitu: siswa memiliki motivasi yang tinggi, memiliki keyakinan dapat mengerjakan lebih banyak tantangan, mampu menilai kapabilitas diri sendiri dengan baik, memiliki kedisiplinan diri, tidak mudah menyerah dalam mengerjakan tugas, memiliki keyakinan untuk membuat goal yang lebih tinggi dari sebelumnya (Eisenberger, Conti-D’Antonio, \& Bertrando, 2014; Schwarzer, 2014). Indikator tersebut dipakai untuk menyusun skala efikasi diri yang digunakan untuk mengukur efikasi diri siswa.

Sama seperti kemampuan penalaranan, kemampuan memecahkan masalah juga termasuk sebagai kompetensi inti di pelajaran matematika di kurikulum nasional (Kemendikbud, 2014) dan kurikulum Cambridge (IGCSE, 2014). Kemampuan tersebut dianggap kompetensi paling penting yang harus diajarkan melalui matematika ( Liljedahl, Santos-Trigo, Malaspina, \& Bruder, 2016) dan juga diproyeksi menjadi salah satu kompetensi inti yang harus dimiliki seseorang untuk bisa sukses di dunia dalam era Industri 4.0 (Grzybowska \& Łupicka, 2017). Ironisnya menurut PISA, kemampuan memecahkan masalah siswa Indonesia masih tergolong rendah (Argina, Mitra, Ijabah, \& Setiawan, 2017; Wulandari \& Zubainur, 2017).

Kemampuan memecahkan masalah adalah kemampuan seseorang dalam memakai kemampuan logika kompleks untuk menyelesaikan masalah dengan cara mengumpulkan fakta, menganalisa informasi yang dikumpulkan, membangun berbagai cara mencari bagian yang hilang dan memilih cara yang paling efektif untuk mencapai suatu tujuan (Attri, 2018). Pemecahan masalah sama dengan belajar, di mana pengetahuan didapat untuk kemudian digunakan dengan efisien untuk menyelesaikan masalah (Soden, 2014).

Pemecahan masalah adalah sebuah aktivitas yang membutuhkan pengetahuan yang sudah dimiliki untuk menemukan apa yang belum diketahui, di mana hal tersebut melibatkan pembuatan hipotesa, mengujinya dan mendapatkan solusi yang memuaskan (Fredericks, 2010). Definisi yang disampaikan oleh Fredericks dan dari teori yang telah disebutkan di atas maka dapat disimpulkan bahwa kemampuan memecahkan masalah adalah kemampuan seseorang dalam menggunakan pengetahuan yang sudah dimiliki untuk menemukan solusi dalam memecahkan masalah yang sedang dihadapi dengan langkah yang tepat.

Permendikbud nomor 58 tahun 2014 menguraikan bahwa indikator kemampuan dalam pemecahan masalah pada siswa adalah siswa mampu 
menunjukkan pemahaman masalah, mampu mengorganisasi data dan memilih informasi yang relevan dalam pemecahan masalah, mampu menyajikan masalah secara matematik, mampu memilih pendekatan dan metode pemecahan masalah secara tepat, mampu membuat dan menafsirkan model matematika dari suatu masalah, dan mampu menyelesaikan masalah yang tidak rutin.

Penelitian mengenai kemampuan penalaran matematis dan memecahkan masalah memang sudah cukup banyak dilakukan namun masih sedikit dilakukan pada siswa sekolah SPK di Jakarta yang memakai kurikulum nasional dan kurikulum Cambridge, padahal kedua kompetensi tersebut menjadi tujuan pelajaran matematika di kedua kurikulum. Dengan menitikberatkan pada penguasaan konsep saja dan menghiraukan kemampuan penalaran, memecahkan masalah tentunya dan efikasi diri akan menimbulkan retentan efek negative terhadap siswa (Kislenko, Grevholm, \& Lepik, 2005; Pepin \& Son, 2015; Pourdavood \& Liu, 2019). Berangkat dari hal tersebut maka tujuan penelitian ini adalah untuk menganalisis pengaruh kemampuan penalaran matematis, kemampuan menyelesaikan masalah dan efikasi diri terhadap penguasaan konsep dalam pelajaran matematika pada siswa kelas empat Sekolah Dasar X.

\section{Metode}

Metode penelitian ini adalah penelitian kausal-komparatif (Gall, Gall, \& Borg, 2006). Penelitian dilakukan di Sekolah Dasar X, Jakarta Barat. Subjek penelitian adalah siswa kelas empat. Populasi dari penelitian ini adalah seluruh siswa kelas empat Sekolah Dasar X. Pengambilan data penelitian ini memakai sensus dikarenakan populasi yang tidak besar dan memungkinkan untuk mengambil keseluruhan sampel dari populasi (Setyawan, 2017), maka data diambil dari keseluruhan siswa kelas empat SD X yang berjumlah 75 siswa. Penelitian ini adalah penelitian populasi sehingga data yang diambil dari keseluruhan subyek penelitian.

Pengolahan data dengan menggunakan analisis jalur. Model penelitian dapat dilihat pada Gambar 1. Dengan empat variabel yaitu penguasaan konsep matematika, kemampuan penalaran matematis, efikasi diri dan kemampuan memecahkan masalah. Dalam penelitian ini, peneliti akan mengidentifikasi pengaruh yang ada antara keempat variabel tersebut.

Berdasarkan penjelasan teoritis atas berbagai pengaruh antar variabel serta hasil penelitian yang relevan maka diajukan lima buah hipotesis dalam penelitian ini (lihat Gambar 1), yaitu: (1) kemampuan penalaran matematis 
berpengaruh positif terhadap penguasaan konsep pelajaran matematika siswa kelas empat Sekolah Dasar X; (2) kemampuan penalaran matematis berpengaruh positif terhadap efikasi diri pada siswa kelas empat Sekolah Dasar X; (3) kemampuan penalaran matematis berpengaruh positif terhadap kemampuan memecahkan masalah pada siswa kelas empat Sekolah Dasar X; (4) efikasi diri berpengaruh positif terhadap penguasaan konsep pelajaran matematika pada siswa kelas empat Sekolah Dasar X; (5) kemampuan memecahkan masalah berpengaruh positif terhadap penguasaan konsep matematika pada siswa kelas empat Sekolah Dasar X.

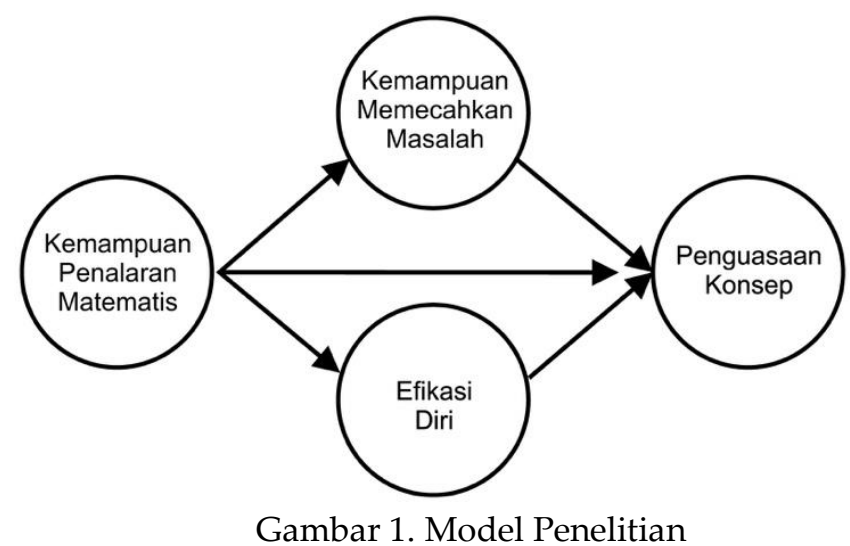

Pengumpulan data dengan penelitian lapangan dilakukan dengan mengukur ke-empat variabel yang terkait pada subyek penelitian. Data tingkat kemampuan penalaran dan kemampuan memecahkan masalah pada subyek penelitian dikumpulkan dengan instrumen berupa tes tertulis yang kemudian dinilai dengan rubrik. Data tingkat penguasaan konsep siswa kelas empat Sekolah Dasar X dikumpulkan dengan dokumentasi nilai delapan ujian matematika pada semester pertama tahun ajaran 2016/2017. Data tingkat efikasi diri subyek penelitian dikumpulkan dengan instrumen berupa angket tertutup skala efikasi diri.

Dalam mengukur penguasaan konsep pada siswa kelas empat SD X dapat digunakan tes sumatif. Penguasaan konsep siswa dapat diukur dengan tes sumatif yang diberikan di akhir satuan pelajaran, sehingga dapat dilihat dari tinggi rendahnya nilai tes, semakin tinggi nilainya berarti siswa semakin sukses siswa menguasai konsep yang diajarkan (Tomei, 2011). Penguasaan konsep yang diukur dalam tes sumatif tersebut adalah penguasaan konsep angka sampai ratusan ribuan, konsep faktor dan kelipatan, konsep perkalian dan pembagian, konsep sudut serta konsep persegi dan bujur sangkar. 
Kemampuan penalaran matematis siswa kelas empat SD X diukur dengan tes tertulis yang kemudian dinilai dengan rubrik. Tes tertulis terdiri dari 13 soal yang dikembangkan untuk disesuaikan dengan indikator-indikator kemampuan penalaran matematis. Rubrik kemampuan penalaran matematis terdiri dari 7 kriteria yang juga dikembangkan melalui indikator-indikator kemampuan penalaran matematis. Rubrik dipilih sebagai instrumen pengukur keterampilan karena rubrik mengurangi tingkat subyektifitas penilaian karena rubrik membantu menjabarkan kriteria yang akan diukur disertai tingkatannya (Brookhart, 2013).

Instrumen efikasi diri adalah skala efikasi diri, di mana responden akan membandingkan tingkat efikasi diri dalam diri mereka terhadap pernyataanpernyataan yang ada. Skala penilaian efikasi diri responden menggunakan skala Likert dengan 4-poin. Lazimnya skala Likert yang digunakan adalah 5poin, namun 4-poin dipilih karena menimbangkan konsitensi kisaran data antar variabel penelitian dan beberapa teori menyarankan menggunakan skala 4-poin pada instrumen yang melibatkan anak-anak ( Nangle, Hansen, Erdley, \& Norton, 2010; Stahl, K. A. D., Flanigan, K., \& McKenna, 2020).

Kemampuan memecahkan masalah siswa kelas empat SD X diukur dengan tes tertulis dan rubrik. Tes tertulis terdiri dari tiga soal cerita yang mengharuskan siswa menyertai tahap penyelesaian dengan bentuk model matematika. Tahap penyelesaian tersebut akan dinilai melalui rubrik kemampuan memecahkan masalah.

Instrumen tes tertulis kemampuan penalaran matematis dan kemampuan memecahkan masalah akan divalidasi oleh ahli pendidikan dan ahli matematika sedangkan skala psikologi efikasi diri akan divalidasi oleh ahli pendidikan dan ahli psikologi. Pada penelitian ini instrumen diuji validitasnya dengan uji validitas isi dan konstruk serta uji coba instrumen. Uji coba instrumen kemampuan penalaran matematis, efikasi diri dan memecahkan masalah dilakukan terhadap 25 responden yang memiliki kemiripan dengan subyek penelitian. Data hasil uji coba serta data penguasaan konsep yang didapat dari dokumentasi diuji distribusinya dan kemudian diuji validitas (Pearson product moment) dan reliabilitas (Cronbach Alpha) dengan didahului oleh uji normalitas data (Chi Kuadrat).

\section{Hasil dan Pembahasan}

Hasil dari uji instrumen, ditemukan bahwa instrumen penguasan konsep semuanya valid dan reliabel (0.933). Dalam uji validitas instrumen kemampuan penalaran matematis, satu butir rubrik dinyatakan tidak valid 
dengan nilai korelasi yang lebih kecil dari $\mathrm{r}_{\text {tabel }}$ untuk derajat kepercayaan hingga 95\%, butir rubrik tersebut tidak akan dibuang melainkan tingkat kesulitan akan diperbaiki atau disesuaikan. Pada uji validitas skala efikasi diri ditemukan terdapat 3 deskriptor tidak valid dengan nilai korelasi yang lebih kecil dari rtabel (0.396) untuk derajat kepercayaan hingga 95\%, sebagian akan dipertahankan dan sebagian akan dibuang. Pada uji instrumen kemampuan memecahkan masalah ditemukan bahwa semua butir rubrik valid dan reliabel (0.954).

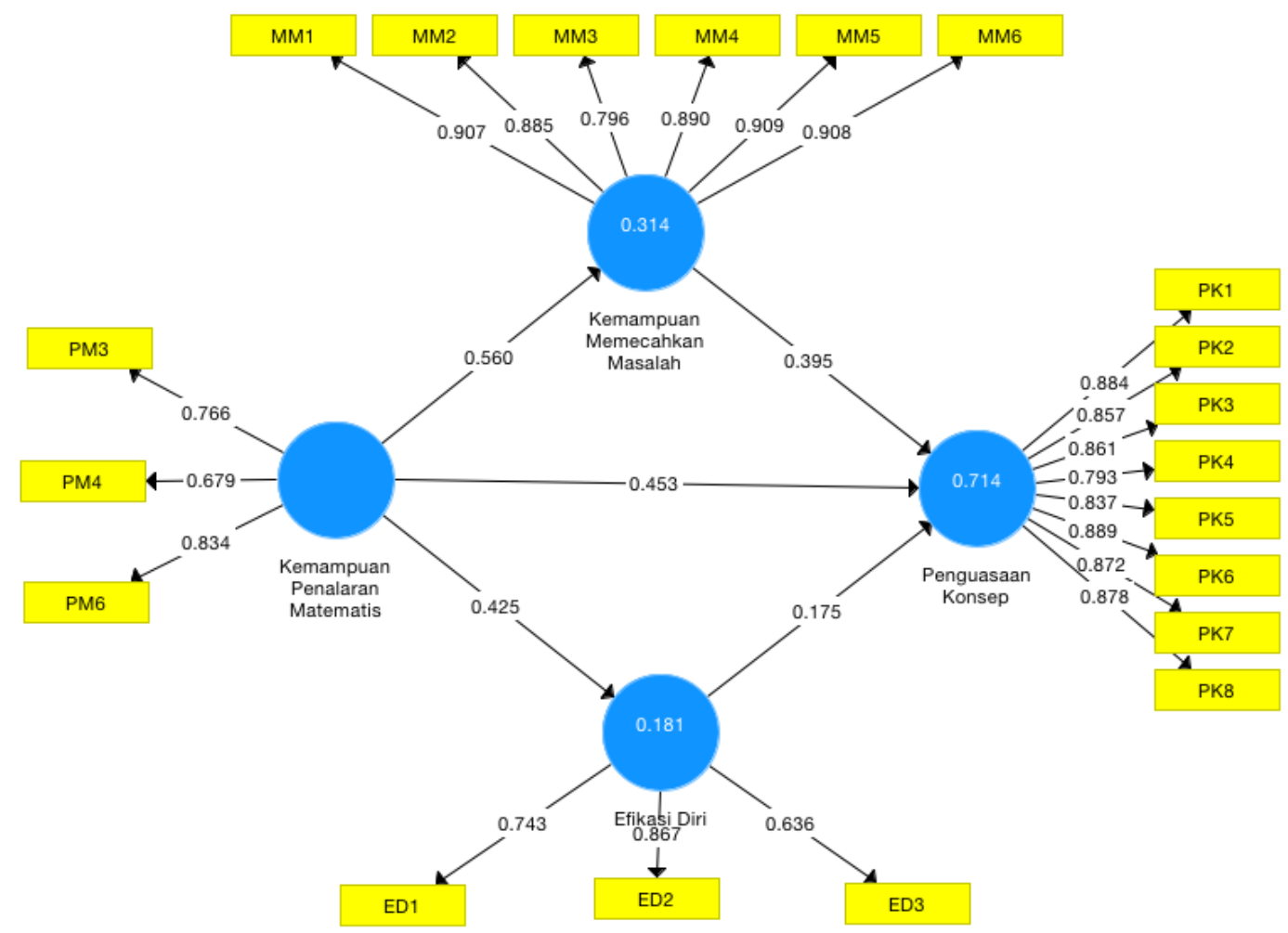

Gambar 2. Model Struktural Setelah Uji Model dengan SmartPLS 3.0

Model persamaan struktural setelah melewati rangkaian uji model dapat dilihat pada Gambar 2. Angka yang berada di dalam lingkaran adalah nilai $R$-squared atau koefisien determinasi yaitu besaran kemampuan variabel laten dalam menjelaskan varian variabel laten yang terhubung dengan jalur pengaruh (Woodhouse, 2003). Pada variabel laten efikasi diri, melalui hasil pengolahan data, didapat nilai $R$-squared sebesar 0,181 yang berarti variabel kemampuan penalaran matematis menjelaskan variabel efikasi diri sebesar $18,1 \%$. Nilai $R$-squared pada kemampuan memecahkan masalah adalah 0,314 yang berarti variabel kemampuan penalaran matematis mampu menjelaskan variabel kemampuan memecahkan masalah sebesar 31,4\%. Pada variabel penguasaan konsep nilai $R$-squared sebesar 0,714 yang berarti sebesar 71,4\% 
dijelaskan oleh variabel kemampuan penalaran matematis, efikasi diri dan kemampuan memecahkan masalah dan 38,6\% (100\% - 71,4\%) dijelaskan oleh faktor-faktor lain.

Dengan keseluruhan jalur pengaruh memiliki koefisien jalur lebih besar dari nol maka dapat disimpulkan bawa variabel laten kemampuan penalaran matematis memiliki pengaruh positif terhadap penguasaan konsep, efikasi diri dan kemampuan memecahkan masalah, serta efikasi diri dan kemampuan memecahkan masalah memiliki pengaruh positif terhadap penguasaan konsep. Rangkuman koefisien jalur pada kelima jalur pengaruh dapat dilihat pada Tabel 1.

Tabel 1. Koefisien Jalur Pada Kelima Jalur Pengaruh

\begin{tabular}{ccc}
\hline \multicolumn{2}{c}{ Jalur Pengaruh } & Koefisien Jalur \\
\hline Kemampuan Penalaran Matematis & Penguasaan Konsep & 0,453 \\
Kemampuan Penalaran Matematis & Efikasi Diri & 0,425 \\
Kemampuan Penalaran Matematis & Kemampuan Memecahkan & 0,560 \\
Efikasi Diri & Masalah & 0,175 \\
Kemampuan Memecahkan Masalah & Penguasaan Konsep & 0,395 \\
\hline
\end{tabular}

Tabel 1 menunjukkan koefisien jalur antara kemampuan penalaran matematis terhadap penguasaan konsep adalah 0,453. Nilai tersebut menyatakan bahwa kemampuan penalaran matematis siswa kelas empat SD $X$ berpengaruh langsung positif terhadap tingkat penguasaan konsep di dalam pelajaran matematika. Berpengaruh positif artinya adalah semakin terampil siswa dalam penalaran matematis maka semakin tinggi tingkat penguasaan konsep siswa tersebut di dalam pelajaran matematika, dan sebaliknya, bila kemampuan penalaran matematis siswa rendah maka tingkat penguasaan konsep juga rendah.

Penemuan penelitian ini mengenai kemampuan penalaran matematis berpengaruh positif terhadap penguasaan konsep matematika menguatkan teori yang disampaikan oleh Ben-Hur (2006) yang menjabarkan bahwa kemampuan seseorang dalam menguasai sesuatu yang konseptual adalah hasil dari reflektif dengan menggunakan kemampuan kognitif-nya, bukan dari hasil menghafal. Para ahli konstruktivisme berpendapat bahwa proses reflektif dengan kognitif adalah mengkaitkan konsep yang baru dengan konsep yang sudah dimiliki, keberhasilan proses tersebut sangat bergantung oleh kemampuan penalaran. Seperti pendapat Killpatrick et al (Brodie Coetzee, Lauf, Modau, Molefe, \& O’Brien, 2010) yang menyatakan bahwa 
kemampuan penalaran matematis adalah kemampuan menghubungkan konsep dan prosedur matematika dalam cara yang masuk akal.

Penemuan adanya pengaruh positif kemampuan penalaran matematis terhadap penguasaan konsep juga memperkuat penemuan terdapat pengaruh kemampuan penalaran terhadap prestasi siswa dalam pelajaran matematika (Riyanto \& Siroj, 2014). Prestasi siswa pada penelitian tersebut memakai acuan yang sama dengan penguasaan konsep yaitu nilai tes sumatif. Selain itu, kemampuan penalaran matematis dan penguasaan konsep sama-sama meningkat dengan satu perlakuan yang sama, yaitu pembelajaran kooperatif think-pair-square, yaitu salah satu metode pengajaran interaktif yang mengharuskan siswa bekerja berpasangan kemudian bersama dalam kelompok (Strebe, 2013). Pembelajaran kooperatif think-pair-square menurut penelitian Sabilulungan (Sumaryati, 2013), dapat meningkatkan kemampuan penalaran matematis siswa SMP dan pembelajaran yang sama juga dapat meningkatkan kemampuan pemahaman konsep matematis siswa SMA di Cimahi. Kemampuan pemahaman konsep matematis pada penelitian tersebut memiliki indikator yang sama dengan penguasaan konsep yaitu taksonomi Bloom.

Hasil pengolahan data menunjukkan koefisien jalur antara kemampuan penalaran matematis terhadap efikasi diri adalah 0,425. Nilai tersebut menyatakan bahwa kemampuan penalaran matematis siswa kelas empat SD $X$ berpengaruh langsung positif terhadap efikasi diri mereka. Berpengaruh positif artinya adalah semakin terampil siswa dalam penalaran matematis maka semakin tinggi tingkat efikasi diri siswa tersebut di dalam pelajaran matematika, dan sebaliknya, bila kemampuan penalaran matematis siswa rendah maka semakin rendah pula tingkat efikasi dirinya.

Pengaruh positif kemampuan penalaran matematis terhadap efikasi diri memperkuat penemuan Salthouse (2016), yang mengemukakan bahwa beberapa penelitian menunjukkan adanya hubungan pengaruh antara efikasi diri dan kemampuan kognitif. Salah satu contoh adalah efikasi diri seseorang akan semakin menurun bila kemampuan penalarannya menurun. Juga ditemukan hal yang sama ketika membandingkan anak muda dan orangtua yang memiliki tingkat penalaran berbeda, didapat juga bahwa kemampuan penalaran yang baik pada anak muda membuat mereka memiliki efikasi diri yang lebih baik dari orangtua yang memiliki akurasi yang rendah dalam uji penalaran. Hal tersebut dapat diartikan bahwa kemampuan penalaran memiliki pengaruh yang positif terhadap efikasi diri. 
Berdasarkan hasil pengolahan data menunjukkan koefisien jalur antara kemampuan penalaran matematis terhadap penguasaan konsep adalah 0,560 . Nilai tersebut menyatakan bahwa kemampuan penalaran matematis siswa kelas empat SD $X$ berpengaruh langsung positif terhadap tingkat kemampuan memecahkan masalah di dalam pelajaran matematika. Berpengaruh positif artinya adalah semakin baik kemampuan siswa dalam penalaran matematis maka semakin tinggi kemampuan siswa tersebut dalam memecahkan masalah matematika, dan sebaliknya, bila kemampuan penalaran matematis siswa rendah maka kemampuan memecahkan masalah juga rendah.

Dengan ditemukannya bahwa kemampuan penalaran matematis memberikan pengaruh yang positif terhadap kemampuan memecahkan masalah hal tersebut menyatakan bahwa penalaran adalah termasuk di dalam kemampuan memecahkan masalah dikarenakan kedua hal tersebut sangat besar kaitannya satu sama lain (Shaffer \& Kipp, 2010). Penalaran dibutuhkan untuk menyelesaikan masalah dengan menggunakan hal yang telah diketahui untuk membantu mengerti hal yang belum diketahui.

Dengan ditemukan pengaruh yang bersifat positif antara penalaran matematis dan kemampuan memecahkan masalah maka sangat penting meningkatkan kemampuan penalaran matematis bila siswa ingin memiliki kemampuan memecahkan masalah yang baik. Sejalan dengan hal tersebut, hasil penelitian Wasiran \& Andinasari (2019) menunjukan pembelajaran berbasis creative problem solving dapat secara efektif meningkatkan kemampuan penalaran. Salah satu alasan penalaran matematis sangat dibutuhkan adalah untuk memecahkan masalah dengan solusi yang tepat (Kariadinata, 2012). Hal tersebut berlaku sebaliknya, yaitu prosedur langkahlangkah proses memecahkan masalah yang tepat dapat membantu siswa lebih percaya diri dalam menghadapi masalah dalam tugas di berbagai kondisi serta meningkatkan kemampuan penalaran mereka.

Menurut penelitian Permana \& Sumarmo (2007) ditemukan bahwa kemampuan penalaran matematis siswa semakin meningkat bila melakukan pembelajaran berbasis masalah. Peningkatan kemampuan penalaran matematis dengan pembelajaran berbasis masalah juga ditemukan dalam penelitian Herman (2007) dengan subyek penelitian siswa kelas dua Sekolah Menengah Pertama (SMP) di Bandung.

Penelitian terhadap siswa kelas dua dilakukan oleh Muchlis (2012), penelitian tersebut menemukan bahwa dengan pendekatan Pendidikan 
Matematika Realistik Indonesia (PMRI) yaitu pembelajaran yang terpusat pada siswa dengan memakai permasalahan yang terjadi di dunia nyata, kemampuan penalaran matematis siswa dan kemampuan memecahkan masalah sama-sama mengalami peningkatan. Demikian dengan pembelajaran dengan pendekatan metakognitif grup (PPMG) atau pembelajaran dengan pendekatan metakognitif klasikal (PPMK) menurut penelitian Amin (2011) juga dapat meningkatkan kemampuan penalaran dan kemampuan pemecahan masalah secara bersamaan.

Berdasarkan hasil pengolahan data menunjukkan koefisien jalur antara kemampuan penalaran matematis terhadap penguasaan konsep adalah 0,175 . Nilai tersebut menyatakan bahwa kemampuan penalaran matematis siswa kelas empat SD $X$ berpengaruh langsung positif terhadap tingkat kemampuan memecahkan masalah di dalam pelajaran matematika. Berpengaruh positif artinya adalah semakin baik kemampuan siswa dalam penalaran matematis maka semakin tinggi kemampuan siswa tersebut dalam memecahkan masalah matematika, dan sebaliknya, bila kemampuan penalaran matematis siswa rendah maka kemampuan memecahkan masalah juga rendah.

Pembuktian bahwa adanya pengaruh positif efikasi diri terhadap penguasaan konsep memperkuat hasil penelitian Ambarwati (2014) yaitu efikasi diri dan prestasi belajar matematika sama-sama meningkat dengan perlakuan yang sama yaitu praktik scaffolding. Prestasi belajar pada penelitian tersebut memakai instrumen yang sama dengan variabel penguasaan konsep pada penelitian ini yaitu, dokumentasi nilai tes sumatif.

Hasil pengolahan data menunjukkan koefisien jalur antara kemampuan memecahkan masalah terhadap penguasaan konsep adalah 0,395. Nilai tersebut menyatakan bahwa kemampuan memecahkan masalah siswa kelas empat SD X berpengaruh langsung positif terhadap tingkat penguasaan konsep di dalam pelajaran matematika. Berpengaruh positif artinya adalah semakin baik kemampuan siswa dalam memecahkan masalah maka semakin tinggi tingkat penguasaan konsep siswa dalam pelajaran matematika, dan sebaliknya, bila kemampuan memecahkan masalah pada siswa rendah maka penguasaan konsep matematika juga rendah.

Penemuan penelitian ini mengenai pengaruh positif kemampuan memecahkan masalah terhadap penguasaan konsep matematika menguatkan teori yang disampaikan oleh Sigelman \& Rider (2009) bahwa penguasaan konsep matematika dapat meningkatkan kemampuan siswa 
dalam menyelesaikan permasalahan matematis. Selain hal tersebut, penemuan tersebut juga melengkapi penemuan dari penelitian Silaban (2014) pada siswa SMA di Medan yaitu adanya hubungan yang positif dan signifikan antara penguasaan konsep dan kemampuan memecahkan masalah.

\section{Simpulan}

Hasil penelitian ini menghasilkan kesimpulan bahwa: 1) kemampuan penalaran matematis siswa mempengaruhi secara positif penguasaan konsep pada pelajaran matematika; 2) kemampuan penalaran matematis siswa mempengaruhi secara positif efikasi diri siswa; 3) kemampuan penalaran matematis siswa mempengaruhi secara positif kemampuan siswa dalam memecahkan masalah; 4) Efikasi diri siswa mempengaruhi secara positif penguasaan konsep pada pelajaran matematika; 5) Kemampuan siswa dalam memecahkan masalah mempengaruhi secara positif penguasaan konsep pada pada pelajaran matematika. Penguasaan konsep sejatinya masih menjadi acuan utama bagi Sekolah $X$ untuk menyatakan ketuntasan seorang siswa mengikuti pelajaran matematika. Melalui penemuan penelitian ini yaitu kemampuan penalaran matematis dan kemampuan memecahkan masalah memiliki pengaruh positif terhadap penguasaan konsep, sehingga Sekolah $X$ juga harus turut memperhatikan kedua hal tersebut dalam pelajaran matematika. Efikasi diri juga turut memberikan pengaruh positif terhadap penguasaan konsep. Oleh sebab itu guru dapat memberikan perlakukan agar efikasi diri siswa meningkat seperti siswa diberi goal jangka pendek yang realistis untuk dicapai dengan strategi pembelajaran yang spesifik dan diberikan reward atas pencapaian mereka. Ketika guru memberikan perhatian khusus pada hal tersebut maka besar kemungkinan siswa dapat memiliki penguasan konsep yang tinggi.

\section{Daftar Pustaka}

Ambarwati, Y. (2014). Pengaruh Praktik Scaffolding Terhadap Peningkatan Self-Efficacy dan Prestasi Belajar Matematika Siswa Kelas 3 SD Dalam Soal Cerita Tentang Konsep Comparing. Pelita Harapan University.

Amin, M. F. (2011). Peningkatan Kemampuan Koneksi Matematis Dan Kemandirian Siswa Dengan Pendekatan Pembelajaran Metakognitif Di Sekolah Menengah Pertama. Building the Nation Character through Humanistic Mathematics Education, 978-979.

Argina, A. W., Mitra, D., Ijabah, N., \& Setiawan, R. (2017). Indonesia PISA Result: What Factors and What Should be Fixed? The 1st Educational and Language International Conference Proceedings Center for International Developmentof Unissula, 69-79.

Attri, R. (2018). Accelerating complex problem-solving skills: problem-centered training design methods. Singapore: Speed To Profciency Research: S2PRo.

Ben-Hur, M. (2006). Concept-Rich Mathematics Instruction: Building a Strong Foundation for Reasoning and Problem Solving. ASCD. 
Brodie, K., Coetzee, K., Lauf, L., Modau, S., Molefe, N., \& O’Brien, R. (2010). Teaching Mathematical Reasoning in Secondary School Classrooms. Springer, Boston, MA.

Brookhart, S. M. (2013). How to Create and Use Rubrics for Formative Assessment and Grading. Association for Supervision \& Curriculum Development.

Dogan, U. (2015). Student engagement, academic self-efficacy, and academic motivation as predictors of academic performance. Anthropologist, 20(3), 553-561.

Eisenberger, J., Conti-D'Antonio, M., \& Bertrando, R. (2014). Self-Efficacy: Raising the Bar for All Students, Second. Eye On Education.

Fitzpatrick, A. (2018). Technology Use, Students' Math Self-efficacy, Goal Orientation, and Math Achievement in Guatemala. Fordham University.

Fredericks, A. (2010). The Teacher's Handbook: Strategies For Success. Pymouth: Rowman \& Littlefield Education.

Gall, M. D., Gall, J. P., \& Borg, W. R. (2006). Educational Research: An Introduction, 8th Edition. Educational An Introduction.

Stahl, K. A. D., Flanigan, K., \& McKenna, M. C. (2020). Assessment for Reading Instruction. Guilford Publications.

Garry, T. (2020). Mastery in Primary Mathematics: A Guide for Teachers and Leaders. Bloomsburry Publishing.

Grzybowska, K., \& Łupicka, A. (2017). Key competencies for Industry 4.0. Economics and Management Innovations (ICEMI), 1(March 2018), 250-253.

Gusniwati, M. (2015). Pengaruh Kecerdasan Emosional dan Minat Belajar terhadap Penguasaan Konsep Matematika Siswa SMAN di Kecamatan Kebon Jeruk. Formatif: Jurnal Ilmiah Pendidikan MIPA.

Herman, T. (2007). Pembelajaran Berbasis Masalah untuk Meningkatkan Kemampuan Berpikir Matematis Tingkat Tinggi Siswa Sekolah Menengah Pertama. Educationist, 1(1), 47-56.

Higgins, K. N., Crawford, L., Angelo, J. H.-D., \& Horney, M. (2015). Investigating Student Use of Electronic Support Tools and Mathematical Reasoning. Contemporary Educational Technology, 7(1), 1-24.

IGCSE, C. (2014). Cambridge IGCSE ® Additional Mathematics. Cambridge University

Kariadinata, R. (2012). Menumbuhkan Daya Nalar (Power of Reason) Siswa Melalui Pembelajaran Analogi Matematika. Infinity Journal 1(1), 10-18.

Kemendikbud. (2014). Peraturan Mendikbud Nomor 58 tahun 2014 tentang Kurikulum 2013 Sekolah Menengah Pertama (SMP) / Madrasah Tsanawiyah (MTs), 1-109.

Kislenko, K., Grevholm, B., \& Lepik, M. (2005). Mathematics is important but boring: Students' beliefs and attitudes towards mathematics. In Nordic Conference on Mathematics Education: 02/09/2005-06/09/2005, 349-360. Tapir Academic Press.

Liljedahl, P., Santos-Trigo, M., Malaspina, U., \& Bruder, R. (2016). Problem Solving in Mathematics Education. Springer, Cham.

McInerney, D. M. (2014). Educational Psychology - Constructing Learning. In Victorian Reports.

Mevarech, Z., \& Kramarski, B. (2014). Critical Maths for Innovative Societies. OECD.

Muchlis, E. (2012). Pengaruh Pendekatan Pendidikan Matematika Realistik Indonesia (PMRI) Terhadap Perkembangan Kemampuan Pemecahan Masalah Siswa II SD Kartika 1.10 Padang. EXACTA. 10(2), 136-139.

Nangle, D. W., Hansen, D. J., Erdley, C. A., \& Norton, P. J. (2010). Practitioner's Guide to Empirically Based Measures of Social Skills. New York: Springer.

Nickerson, R. S. (2011). Mathematical Reasoning: Patterns, Problems, Conjectures, and Proofs. Taylor \& Francis. 
Olivier, E., Archambault, I., De Clercq, M., \& Galand, B. (2019). Student Self-Efficacy, Classroom Engagement, and Academic Achievement: Comparing Three Theoretical Frameworks. Journal of Youth and Adolescence, 48(2), 326-340.

Ormrod, J. E. (2012). Human Learning 6th Edition. Pearson Education, Inc.

Pepin, B., \& Son, J.-W. (2015). Motivation, Beliefs, and Attitudes Towards Mathematics and Its Teaching. In The Proceedings of the 12th International Congress on Mathematical Education, 523-527.

Permana, Y., \& Sumarmo, U. (2007). Mengembangkan Kemampuan Penalaran dan Konekso Matematik Siswa SMA Melalui Pembelajaran Berbasis Masalah. Educationist, 1(2), 116123.

Pourdavood, R. G., \& Liu, X. (2019). Confrontation and reconstruction of beliefs and attitudes towards mathematics. International Journal of Learning, Teaching and Educational Research, 18(1), 311-328.

Ratnasari, G. I., \& Abadi, A. M. (2018). Investigating Mathematical Literacy, Mathematical Reasoning Skill, and Self Esteem of a Public High School. Journal of Physics: Conference Series, 1097(1).

Riyanto, B., \& Siroj, R. A. (2014). Meningkatkan Kemampuan Penalaran dan Prestasi Matematika dengan Pendekatan Konstruktivisme Pada Siswa Sekolah Menengah Atas. Jurnal Pendidikan Matematika, 5(2), 111-128.

Salthouse, T. A. (2016). Theoretical Perspectives on Cognitive Aging. In Theoretical Perspectives on Cognitive Aging.

Santrock, J. W. (2011). The Information Processing Approach. Educational Psychology. 5th Ed. New York, McGraw Hill, 271-3.

Schwarzer, R. (2014). Self-Efficacy: Thought Control Of Action. Taylor \& Francis.

Setyawan, F. (2017). Pengantar Metodologi Penelitian. Jakarta: Zifatama Jwara.

Shaffer, D., \& Kipp, K. (2010). Developmental Psychology: Childhood and Adolescence (Eight Edit). Belmont: Wadsworth Publishing.

Sigelman, C. K., \& Rider, E. A. (2009). Life-Span Human. Development. 6th. Belmont, CA: Wadsworth. Cengage Learning.

Silaban, B. (2014). Hubungan Antara Penguasaan Konsep Fisika dan Kreativitas Dengan Kemampuan Memecahkan Masalah Pada Materi Pokok Listrik Statis. Jurnal Penelitian Bidang Pendidikan, 20(I), 65-75.

Soden, R. (2014). Teaching Problem Solving in Vocational Education. New York: Routledge.

Strebe, J. (2013). Engaging Mathematics Students Using Cooperative Learning. New York: Routledge.

Sukirwan, Darhim, D., \& Herman, T. (2018). Analysis of students' mathematical reasoning. Journal of Physics: Conference Series, 948(1).

Sumaryati, E. (2013). Pendekatan Induktif-Deduktif Disertai Strategi Think-Pair-SquareShare Untuk Meningkatkan Kemampuan Pemahaman dan Berpikir Kritis Serta DIsposisi Matematis Siswa SMA. Infinity Journal, 2(1), 26-42.

Tomei, L. A. (2011). Designing Instruction for The Traditional, Adult, and Distance Learner: a New Engine for Technology-Based Teaching. Turkish Online Journal of Distance Education, 12(4), 212-224.

Wasiran, Y., \& Andinasari, A. (2019). Meningkatkan Kemampuan Berpikir Kreatif dan Penalaran Adaptif Matematika Melalui Paket Instruksional Berbasis Creative Problem Solving. JNPM (Jurnal Nasional Pendidikan Matematika), 3(1), 51-65.

Wentzel, K. R., \& Miele, D. B. (2016). Handbook of Motivation at School: Second Edition. Routledge.

Wong, B. (2004). Learning About Learning Disabilities. Elsevier. 
Woodhouse, R. (2003). Statistical Regression Line-Fitting In The Oil and Gas Industry. Oklahoma: PennWell Corporation.

Wulandari, S., \& Zubainur, C. M. (2017). Students' Ability in Solving PISA Problems. The 7th Annual International Conference (AIC) Syiah Kuala University and The 6th International Conference on Multidisciplinary Research (ICMR) in Conjuction with the International Conference on Electrical Engineering and Informatics (ICELTICs). 